\title{
Estimating Crop Water Requirements and Assessing Irrigation Water Distribution Cost for Rice Production Using a Pipe Network
}

\author{
Nitish Kumar Gautam, Shibayan Sarkar* \\ Department of Mechanical Engineering, Indian Institute of Technology (ISM), Dhanbad \\ Jharkhand 826004, India
}

Received: 31 May 2017

Accepted:6 August 2017

\begin{abstract}
In this paper we attempted to estimate crop water requirement for rice production in an Indian state. We also assessed the cost of irrigation water distribution. The study area (phases I and II) belongs to a humid subtropical region with sandy clay loam soil. Here, farmers are presently using a partial border strip irrigation technique with supply pipe and riser. First, the Man Kendall test is performed on six years monthly rainfall data to check for the presence of a trend. We found that the data is random at a 5\% significant level. Thereafter, the crop water requirement for rice production is calculated based on FAO guidelines and average monthly rainfall. The crop water requirement in the study area amounted to $7.22 \mathrm{lakh} \mathrm{m}^{3}$, of which Phase I is $6.12 \mathrm{lakh} \mathrm{m}^{3}$ and Phase II is 1.2 lakh $\mathrm{m}^{3}$. In order to fulfil this requirement, irrigation was conducted through a pipe network. Actual irrigation value is calculated based on four years of irrigation water distribution data. Finally, the average depth of water logging, time of pumping, and cost for surplus irrigated water are calculated. We found that at a rate of INR 5 per unit $\mathrm{kWh}$, the cost of annual surplus irrigated water for rice is 4.32 lakhs for an irrigation area of $1.284 \mathrm{~km}^{2}$ (phase I), and the same is INR 0.84 lakh for $0.252 \mathrm{~km}^{2}$ (phase II). This loss can be minimized using proper scheduled regulation of irrigated water using the pipe distribution network.
\end{abstract}

Keywords: irrigation, water distribution network, rice, cost, crop water requirement

\section{Introduction}

Usually in India, irrigation is done by open a channel (viz., canal, drainage channel, etc.). This process is prone to evaporation loss and infiltration loss if the canal is uncovered and unlined. Moreover, where ready surface water sources like a reservoir, lake, river, and canal are unavailable, a submersible pump is installed and used

*e-mail: shibayan.sarkar@gmail.com for irrigation, mostly without knowing about its adverse effects on groundwater for the future, although several procedures are generally practiced to reduce water demand, viz., cropping restrictions, water allotment in limited ways (quotas), and volumetric charging. Sometimes due to lack of awareness, irrigation water demand is not properly estimated by the farmer for a particular crop in a particular season and soil. As a result, excess water is spread over the land and lost unnecessarily and therefore excess expense goes toward water distribution (WD). 
In view of this, several supporting policies have been taken up by the government to increase irrigation efficiency, viz., the use of drip irrigation methods, optimal irrigation scheduling and their control, water metering, farmer education, etc. But in most cases it is observed that a water distribution network (WDN) system still needs more attention for better performance of irrigation and productivity. In addition to this, it is observed that whatever effort is given in irrigation $\mathrm{WD}$, it is mainly done by individuals.

The status of the problem stated in this proposal should be treated differently in developing and developed countries. In the case of irrigation WD systems, our main attention is given to reducing costs for pumping, and among those some significant studies are presented here. Several researchers, including Reca et al. [1-2], Singh et al. [3], Moradi-Jala et al.[4], and Planess et al. [5] have presented studies on optimizing the number of pumps required for irrigation for a particular area, their types, and best scheduling options. Finally, optimal initial and running costs of pumping systems are suggested. PulidoCalvo [6] has suggested shifting irrigation timing to off-peak hours, and some researchers have suggested applying a predetermined schedule of pump shutoff in order to reduce unaccounted-for operating loads on the electrical power transmission during peak demand periods. In connection to this, several researchers have modelled an automatic control system for optimal pumping schedules based on the status of crop water and soil [7-8]. Furthermore, irrigation distribution network models are calibrated and optimized by researchers using the genetic algorithm (GA) technique [9-10]. Allred and Redman [11] and Rahman et al. [12] applied groundpenetrating radar data to locate agricultural drainage pipelines. Moreover, assessment of the conditions of these drainage pipelines also has been made possible by this radar data in Bangladesh. Pulido-Calvo and GutiérrezEstrada [13] analysed a WD system in Spain's Fuente Palmera irrigation district, which involves a main pipe network consisting of 96 control nodes for water flow and pressure. Cao et al. [14] described the water shortage and food scarcity faced by China due to its huge population and economic growth using a newly developed model, whereas Xiao et al. [15] studied water level in the root area in a flooded paddy field and its adverse effect on paddy field soil. In other literature, Shen et al. estimated regional irrigation water requirement and water supply risk in an arid region of Northwestern China based on data of 1989-2010 [16], whereas the effect of climate change on suitable rice cropping areas, cropping systems, and crop water requirements in southern China has been assessed by Ye et al. [17].

Among significant studies of India, researchers [1822] showed that extreme groundwater use for irrigation affects groundwater resources, which has led to frequent failure of irrigation wells, threatens land productivity, water resource sustainability, and power sector viability. Moreover, it has also been observed that agricultural pumping consumes $31.4 \%$ of total power consumption only in western India, whereas some of the Indian states provide $100 \%$ subsidised electricity. It is also observed that there is merely any accountability of the electricity used for irrigation, as consumed power is not properly metered and sometimes a charge of electricity is decided on the basis of the number of connected loads only [2325]. Singh et al. [26] developed an irrigation technique for rice production with water savings of 40 to 50 percent by changing irrigation depth and time interval. Singh [27] presented the optimized water use and pumping schedule for rice production with no loss in grain yield.

In 2003-04 it was reported by Zekri [28] that power consumed in the agriculture sector is almost $21 \%$ of the total power consumption of India. Out of this, states of Haryana, Gujarat, and Punjab consume more than others. In a similar context, De Moor and Calamai [29] concluded that inefficient water and electrical pricing had an adverse impact on water use efficiency in irrigation systems. On the other hand, northern India, especially Uttar Pradesh, is relatively water-abundant where irrigation using groundwater is the usual practice [30].

In view of the above studies it is clear that groundwater utilization is the most common irrigation practice followed in India due to lack of surface water availability. This costs a handsome amount of total power utilization. The lift irrigation technique is used by individual land owners without knowledge about and concern for the groundwater, and mostly without proper water metering. Therefore, assessing a pipe network for WDN may be a prospective area of research for group irrigation WD on a low-cost basis in order to minimize water loss. These facts may in turn reduce the cost of crop production. In view of the above problem, in this project proposal an attempt has been made to assess the effectiveness of irrigation water distribution cost for rice production using a pipe network. For this purpose, we aim to estimate agricultural water demand and provide a guideline for its proper management for a particular land area in corresponding climatic conditions.

\section{Methodology}

A proposed work is planned in the following order. This work will be a combination of field survey and analytical work. Steps involved in the methodology are depicted in Fig. 1 and described as follows:

1) An agricultural location is to be selected as the proposed study area.

2) Generate a GIS map of the study area using satellite data freely available online from either SRTM or from Bhuwan (ISRO geoportal). Moreover, a soil map, crop patterns, a rainfall map, a surface water body map, a proposed pipe network map, or existing positions of pumps should be entered in the map mentioning all distribution nodes using GPS.

3) Analysis of rainfall data, soil condition and climate condition towards estimation of crop water requirement for production of rice. 


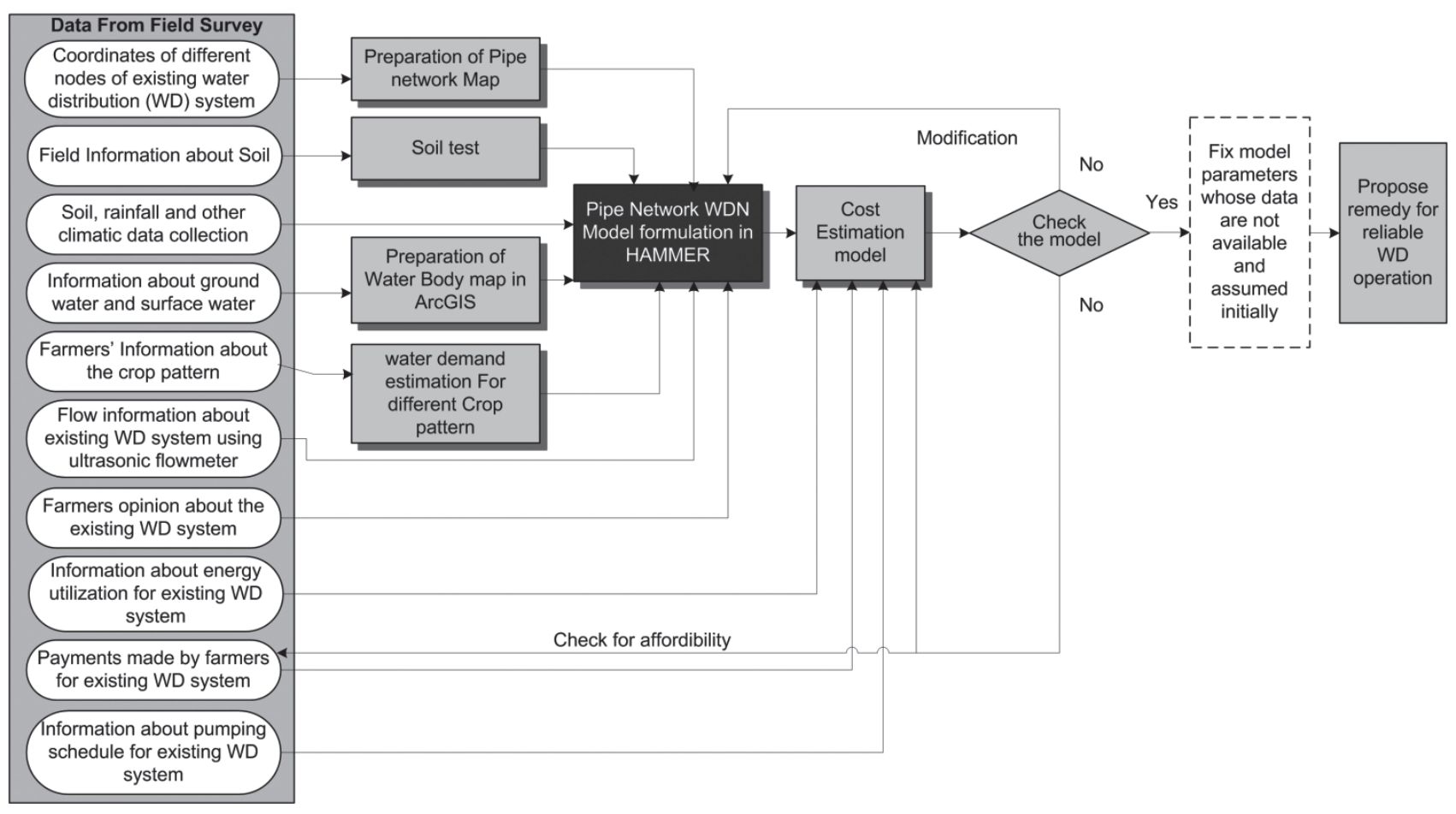

Fig. 1. Flow chart of methodology.

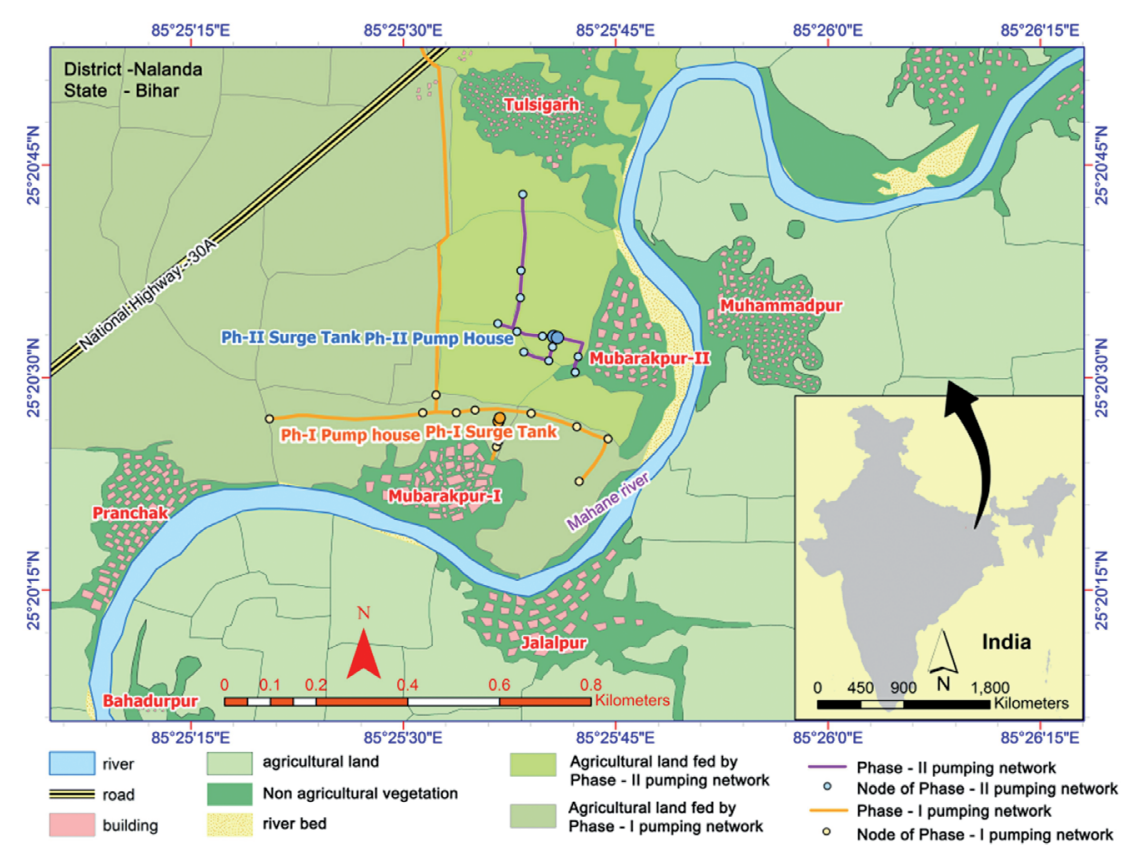

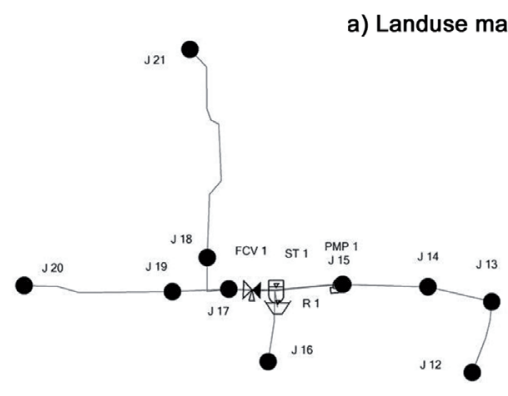

b) Phase I water distribution irrigation piping network

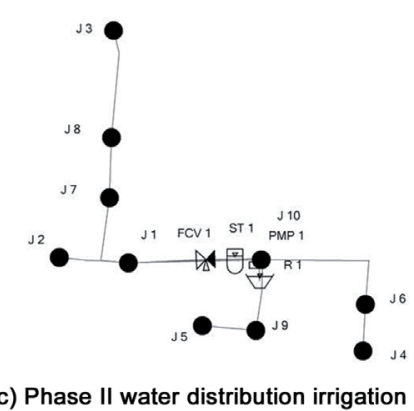

c) Phase II water distribution irrigation piping network

Fig. 2. a) Land use map of study area, b) schematic of Phase I pipe network, and (c) schematic of Phase II pipe network. 
4) Calculate irrigated water through a water distribution network (WDN) in the study area.

5) Calculate differences in crop water requirements and irrigated water and cost estimation for irrigation.

6) Thus, in combination with GPS data and pipe network software a model will be developed for irrigating a WDN system to assess the compatibility of irrigation water distributed through a pipe network. WDN analysis is mainly performed using pipe network software like HAMMER, which considers mass and energy conservation.

\section{Study Area}

A preliminary field survey was performed in some places of Jharkhand and Bihar to find a suitable study area for assessing the prospect of the above said concepts. Among these places, the agricultural area of Gonkura, the Chandi subdivision near Bihar Sharif, Nalkoop Pramandal Bihar Sharif in Nalanda, and Bihar were selected as a study area (Fig. 2). The cultivated area in the district is $1,948.43 \mathrm{~km}^{2}$. Agriculture is the main source of occupation of Nalanda. The farmers mainly grow paddy rice, wheat, potatoes, maize, and onion. This study area is mainly divided into phases I and II based on existing WDN for irrigation. Phase I WDN irrigates $1.28 \mathrm{~km}^{2}$, whereas Phase II irrigates $0.252 \mathrm{~km}^{2}$. Here a small isolated partial pipe network is in operation for irrigation, which was built with the sponsorship of NABARD (Fig. 3a). Pumping stations with submersible pumps are located in different places, which are distributed spatially over this entire study area to withdraw groundwater for distribution nearby.

For each pumping station there are only three pipe outlets in three directions (forward, left, and right) up to the distribution point (node) (Fig. 3b). Usually these pipelines (link) are 100-500 m long. Generally farmers use a pipe and lined channel for water distribution for lands located near the pumping station (Fig. 3c). However, lands situated far away from these distribution points are sometimes fed by flexible pipe or simply an unlined channel. Another interesting fact is that although the Muhane River passes by this area, farmers utilise the groundwater itself without knowing about the groundwater condition of the area, as per the preliminary survey. The groundwater level varies from yield potential 20 to $50 \mathrm{~m}^{3} / \mathrm{hr}$. Hydrogeochemical analysis of a groundwater sample from the study area varies from 6.70 to $7.72 \mathrm{pH}$ [31]. Bihar is an arsenic-prone area. Therefore, withdrawing this huge amount of groundwater may have an adverse effect on the environment in the future. Ultimately, farmers pay a certain amount for the energy utilized for water withdrawal. A preliminary survey shows that farmers are paying for irrigation based on per-unit land area (per decimal basis). There is no water meter in the pumping station. Therefore, there is no restriction in water withdrawal. During the field survey we observed that a huge amount of waterlogging
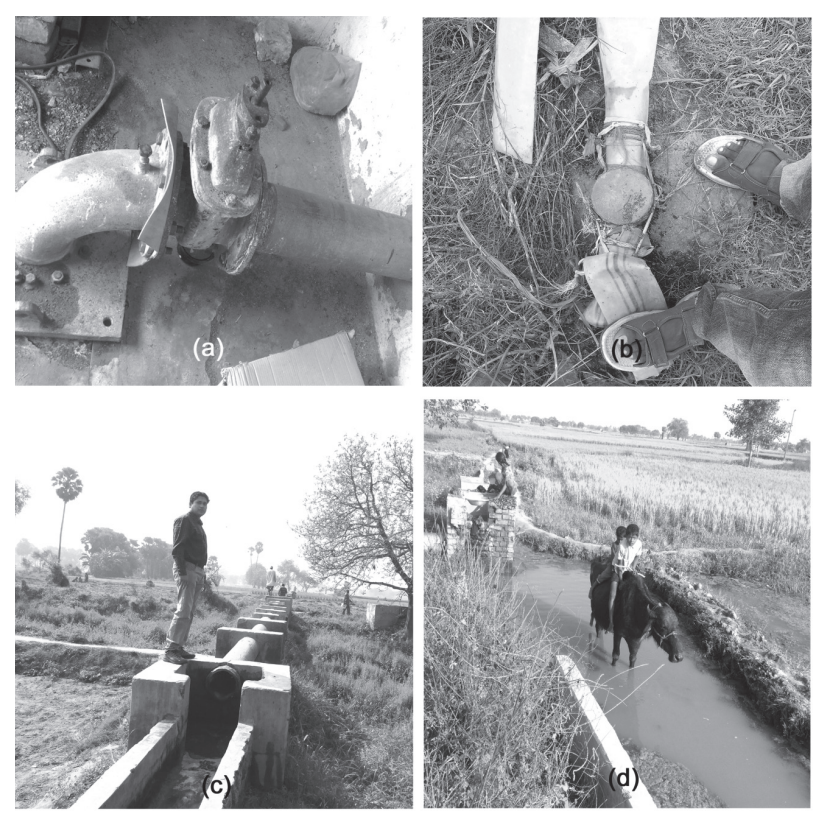

Fig. 3. a) Mubarakpur (Phase I) submersible pumping unit; b) Mubarakpur (Phase I) flexible pipe is installed with the buried main pipeline to feed agricultural land situated in the farthest corner, whenever required; c) in the piping network, in some places, pipe is feeding the lined open channel, which also acts as a levee between two agricultural lands, and d) waterlogged area due to excess water.

occurs in the irrigation area at the end of the crop season (Fig. 3d), resulting in a large financial loss.

During the primary survey we collected soil and water samples. A hygrometry test was conducted regarding soil texture. Moreover, details of climate, irrigation land, and crop patterns corresponding to the pipe network system are shown in Table 1. This study used six years (2004-10) of India Meteorological Department (IMD) rainfall data to find the crop water requirement. A trend test was performed on these data to check for the presence of a trend or any climate change effect on the rainfall data.

Table 1. Details of irrigation land and crop patterns corresponding to the study area.

\begin{tabular}{|c|c|c|}
\hline S1 No & Description & Remark \\
\hline 1. & Eco & $\begin{array}{c}\text { Northern plain, sub-humid eco } \\
\text { region, alluvium derived soil and } \\
\text { GP 150-180 days (NBSSLUP } \\
\text { (National Bureau of Soil Survey } \\
\text { and land Use Planning), 1990) } \\
{[37]}\end{array}$ \\
\hline 2. & Sand texture & $\begin{array}{c}\text { Sandy clay loam } \\
\text { (coarse sandy soil ) }\end{array}$ \\
\hline 3. & Water quality & pH value approx 6.8 \\
\hline 4. & Climate & Humid subtropical \\
\hline
\end{tabular}




\section{Trend Test}

In this study the Man-Kendall test was performed on six years of monthly rainfall data. It is based on the test statistic S defined as (Yue at al., 2002a) [35]:

$$
S=\sum_{i=1}^{n-1} \sum_{j=i+1}^{n} \operatorname{sgn}\left(x_{j}-x_{i}\right)
$$

...where $x_{j}$ is the sequential data values, $\mathrm{n}$ is the length of data set, and:

$$
\operatorname{sgn}(y)=\left\{\begin{array}{r}
1 \ldots \text { if }(y>0) \\
0 \ldots i f(y=0) \\
-1 \ldots i f(y<0)
\end{array}\right\}
$$

It has been documented that when $n \geq 8$, statistic $\mathrm{S}$ is approximately normally distributed with the mean:

$$
E(S)=0
$$

... and variance is:

$$
V(S)=\frac{n(n-1)(2 n+5)-\sum_{i=1}^{m} t_{i}\left(t_{i}-1\right)\left(2 t_{i}+5\right)}{18}
$$

...where $\mathrm{m}$ is the number of tied groups and $t_{j}$ is the size of ith tied groups. The standardized test statistic $\mathrm{Z}$ is computed by:

$$
Z_{M K}=\left\{\begin{array}{c}
\frac{S-1}{\sqrt{\operatorname{Var}(S)}} \text { when } S>0 \\
0 \ldots \text { when } S=0 \\
\frac{S+1}{\sqrt{\operatorname{Var}(S)}} \text { when } S<0
\end{array}\right\}
$$

Finally, based on the results of the trend test, rainfall data will be selected to calculate crop water requirements of the study area.

\section{Crop Water Requirement}

While designing an optimized WD model using a pipe network, water demand at the node is the primary requirement. As per Food and Agriculture Organization (FAO) Irrigation and Drainage Paper 24 Dorenbos and Pruitt [32-34], crop water requirement (ET) is the multiplication of crop coefficient $\left(\mathrm{K}_{c}\right)$ (i.e., indicator of crop characteristics) and reference evapotranspiration (ET) (i.e., indicator of different weather conditions).

$$
E T_{c}=K_{c} \times E T_{o}
$$

The effect of soil evaporation and crop transpiration are included in $\mathrm{K}_{\mathrm{c}}$.

Crop irrigation requirement (CWR) is calculated using the following formula [16].

$$
C W R=E T_{c}-P_{e}
$$

...where $P_{e}$ is effective rainfall. In this case, the U.S. Department of Agriculture's Soil Conservation Service method is used to compute effective rainfall:

$$
P_{e}=\left\{\begin{array}{ll}
P(125-0.2 \times 3 \times P) / 125 & \text { for } \leq 250 / 3 \\
125 / 3+0.1 \times P & \text { for } P>250 / 3
\end{array}\right\}
$$

Whereas is effective rainfall, $\mathrm{P}$ is precipitation [36].

\section{Water Distribution Pipe Network Analysis}

While designing an optimized WD model using a pipe network, the objective function is minimization of total costs involved in water distribution under specific constraints, and that should be satisfied as follows: (i) demands at all nodes must be fulfilled, (ii) node pressure sand flow velocity within a link should be within a specified range, (iii) node demand (except the end one) is to be linked with a minimum of two pipes (link), (iii) the continuity equation must be satisfied at all the nodes, (iii) mass and energy conservation must be maintained for any specified path within the water distribution system, and (iv) pipe diameters should be commercially available. Thus, the minimum decision variables chosen in this optimization model are: (a) pipe diameters, (b) pipe lengths, (c) pump size, (d) reservoir/storage sizes (if applicable), (e) valve locations, and (f) pump capacity (if applicable). Other variables like energy utilized to run the pump, water demand in different seasons related to crop patterns, and rainfall availability and its occurrence may also be incorporated in this model.

A model for branched pipe network systems is described as follows, where $X_{\mathrm{ijm}}$ is the link length of the $\mathrm{m}^{\text {th }}$ link connecting source node $i$ and demand node $j$. The head loss in $\mathrm{m}^{\text {th }}$ link segment can be calculated using the Hazen William formula:

$$
\Delta H_{i j m}=J_{i j m} X_{i j m}
$$

$\mathrm{J}_{\mathrm{ijm}}$ is the gradient, which is defined as:

$$
J_{m}=162.5\left(\frac{Q}{C_{H W}}\right)^{1.852} D^{-4.87}
$$

The following equation is obtained by applying energy conservation law on a specified path connecting nodes 
$i$ and $j$. Here the head at the final node is greater than the specified limit $\mathrm{H}_{\text {min, }}$;

$$
H_{i}-H_{\min , j} \geq \sum_{m} J_{i j m} X_{i j m}
$$

Since the length of any segment is to be always positive, the following non-negativity of $\mathrm{X}_{\mathrm{ijm}}$ prevailed:

$$
X_{i j m} \geq 0
$$

Therefore, the objective function can be written as follows, where the cost of a pipeline in WDN using a pipe network is tried to be kept as minimum as possible under the above-mentioned specific constraints:

$$
\operatorname{Min} z \geq \sum_{i j} \sum_{m} C_{i j m} X_{i j m}
$$

Phases I and II WDN (shown in Fig. 2) are modeled in HAMMER with the information derived from ArcGIS and field survey. A schematic of phases I and II are shown in Figs. 2(b-c), respectively, which are used for WDN analysis in HAMMER.

\section{Result and Discussion}

\section{Trend Test}

Calculating the crop irrigation requirement for rice production for the study area is performed based on six years' (2004-10) of IMD rainfall data (Table 2). The Man Kendall test shows that the value of $\mathrm{s}$ is 69.0 and the value of $\mathrm{Z}$ is 0.2643 . As, the rainfall data series is considered as random at the $5 \%$ significance level (i.e.,no trend is found). Hence, average monthly rainfall values are considered for calculating the crop water requirement.

\section{Calculating Irrigated Water at Different Growth Stages of Rice}

Calculating irrigated water at different growth stages of a crop season based on the existing irrigation techniques in phases I and II WDN are shown in Tables 3-4. Actual irrigation value is calculated based on four years of pipe water distribution data, which are obtained during our field survey. Different crop stages of rice are given in column ii of Table 3. Whereas average irrigated water depth corresponds to different crop stages, the number of times irrigation was done in each stage, and the time required to irrigate one decimal of land, actual irrigation time as per the log book is depicted in columns iv, $v, x$, and $x i$ of Tables 3 and 4.

\section{Estimating Crop Water Requirement as Per FAO}

At different crop stages of rice, ETo values are adopted from FAO and are already mentioned in Table 2 as well. Different crop stages of rice and corresponding Kc and ETo values are given in columns ii, iii, and iv of Tables 5 and 6 for phases I and II of the study area. Finally, ETc is calculated and depicted in column vi of Tables 5 and 6. Effective rainfall and crop water requirements are calculated based on monthly average rainfall data shown in Table 2, which are depicted in column viii of Tables 5 and 6 for phases I and II. Crop water requirement in the study area amounted to 7.22 lakh $\mathrm{m}^{3}$, of which Phase $\mathrm{I}$ is $6.12 \mathrm{lakh}^{3}$ and

Table 2. Calculations of Crop irrigation requirements for Rice production in the study area based on six years (2004-10) of IMD rainfall data.

\begin{tabular}{|c|c|c|c|c|c|}
\hline Months & $\begin{array}{c}\text { Average rainfall } \\
(\mathrm{mm})\end{array}$ & $\begin{array}{c}\text { Effective rainfall } \\
(\mathrm{mm})\end{array}$ & $\begin{array}{c}\text { Effective rainfall } \\
(\mathrm{mm} / \text { day })\end{array}$ & $\begin{array}{c}\text { ETo } \\
(\mathrm{mm} / \text { day })\end{array}$ & $\begin{array}{c}\text { Crop irrigation requirement for Rice } \\
(\mathrm{mm} / \text { day })\end{array}$ \\
\hline January & 18.7 & 17.01 & 0.55 & -- & -- \\
\hline February & 12.3 & 11.61 & 0.41 & -- & -- \\
\hline March & 5.4 & 5.27 & 0.17 & -- & -- \\
\hline April & 12.5 & 11.76 & 0.39 & -- & 6.27 \\
\hline May & 37.3 & 30.61 & 0.99 & 7.256 & 3.86 \\
\hline June & 204.9 & 62.15 & 2.07 & 5.929 & 2.52 \\
\hline July & 246.6 & 66.33 & 2.14 & 4.656 & 0.73 \\
\hline August & 185.6 & 60.22 & 1.94 & 2.67 & -- \\
\hline September & 148.9 & 56.55 & 1.89 & -- & -- \\
\hline October & 29.0 & 24.94 & 0.80 & -- & -- \\
\hline November & 2.6 & 2.60 & 0.09 & -- & -- \\
\hline December & 0.7 & 0.73 & 0.02 & -- & - \\
\hline
\end{tabular}




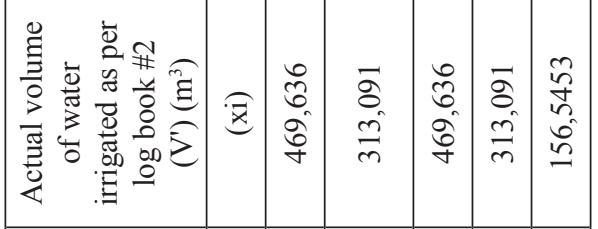

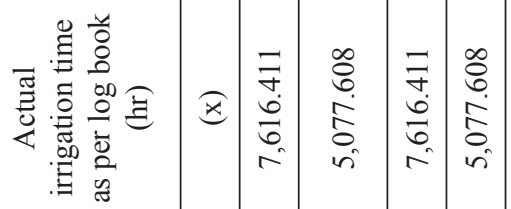

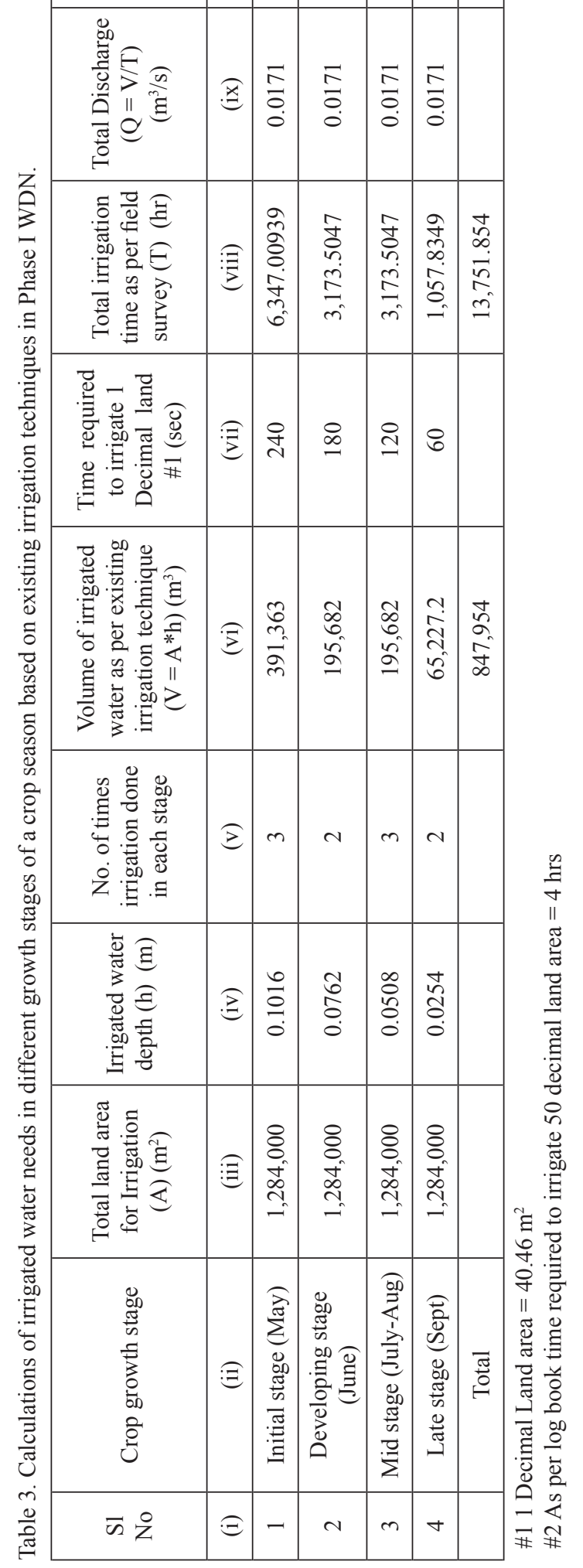

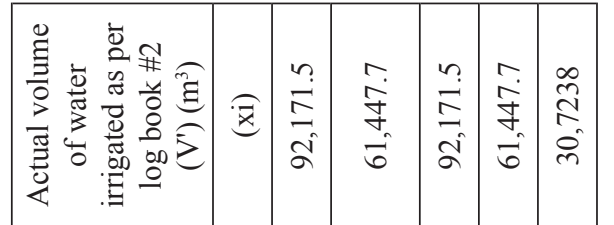

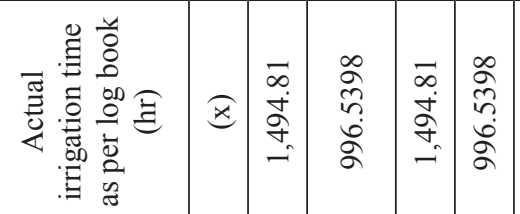

离 $\frac{\widehat{m}}{2}$

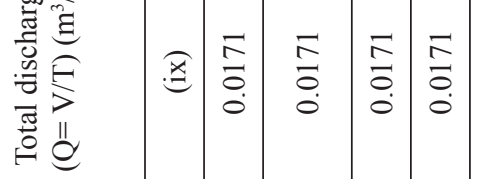

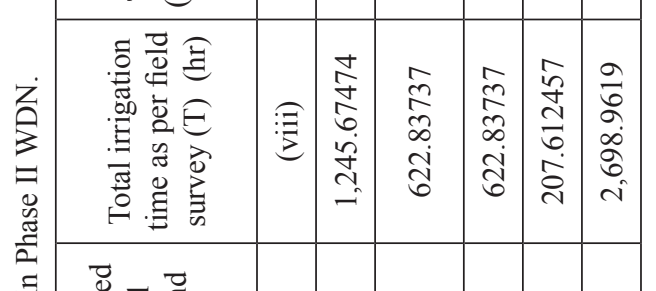

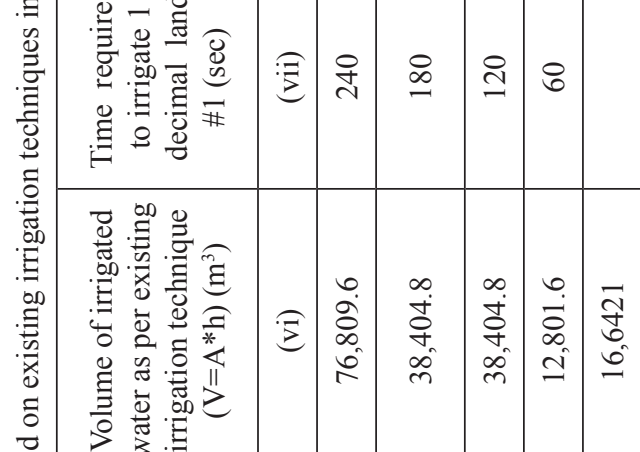

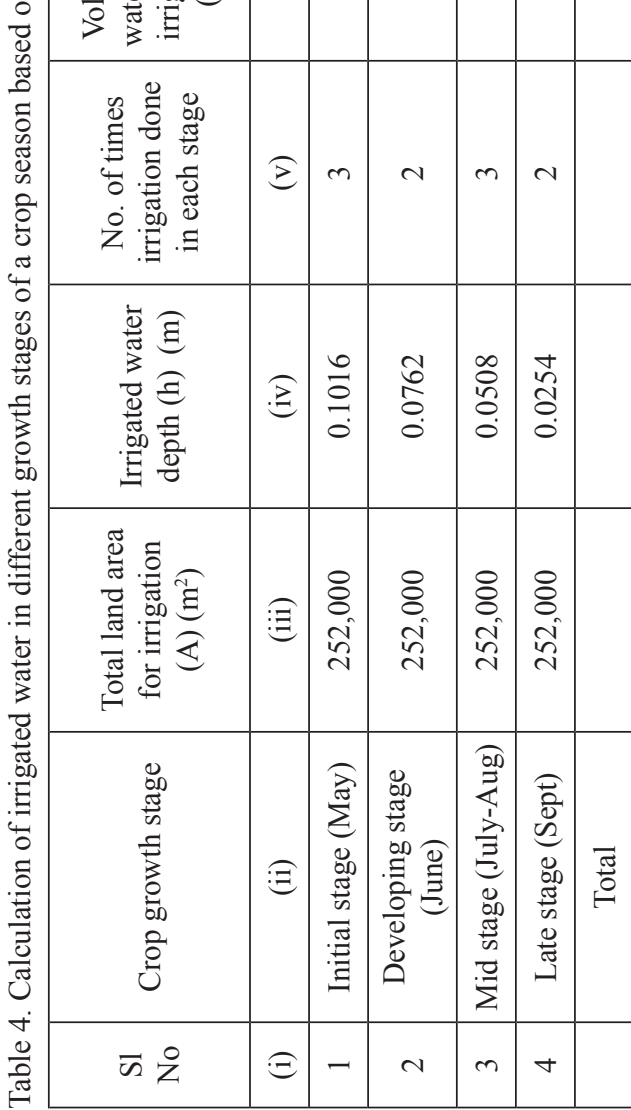




\begin{tabular}{|c|c|c|c|c|c|c|}
\hline 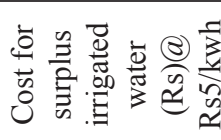 & 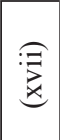 & 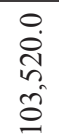 & 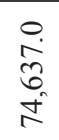 & $\begin{array}{l}\overrightarrow{ \pm} \\
\stackrel{ \pm}{ \pm}\end{array}$ & $\begin{array}{l}\text { jे } \\
\text { ले } \\
\text { ปे }\end{array}$ & \begin{tabular}{|l|l} 
\\
8 \\
0 \\
1 \\
$\gamma$ \\
$\gamma$
\end{tabular} \\
\hline 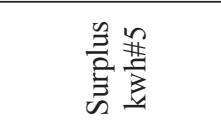 & 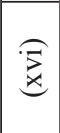 & $\begin{array}{l}0 \\
\dot{8} \\
\stackrel{i}{8} \\
\text { i }\end{array}$ & 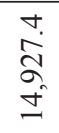 & 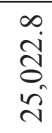 & $\begin{array}{l}0 \\
\dot{0} \\
\infty \\
0 \\
i\end{array}$ & 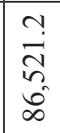 \\
\hline 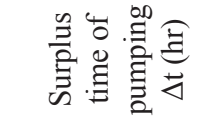 & 胥 & 官 & $\begin{array}{l}0 \\
\dot{0} \\
0 \\
0 \\
i \\
i\end{array}$ & 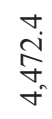 & 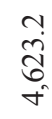 & 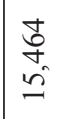 \\
\hline
\end{tabular}

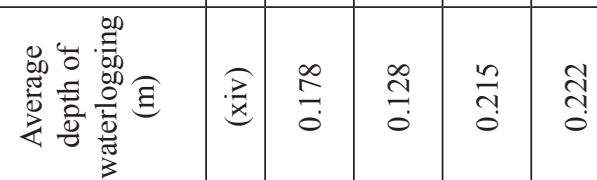

\begin{tabular}{|c|c|c|c|c|}
\hline 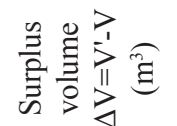 & : 䒝 & 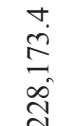 & = & $\begin{array}{l}\overrightarrow{0} \\
\stackrel{8}{*} \\
\text { an } \\
\end{array}$ \\
\hline
\end{tabular}

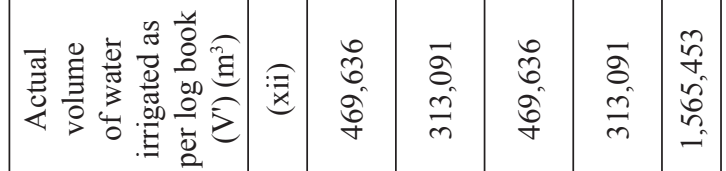

\begin{tabular}{|c|c|c|c|c|}
\hline 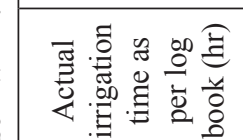 & $\widehat{\otimes}$ & $\begin{array}{l}8 \\
6 \\
0\end{array}$ & $\begin{array}{l}0 \\
\stackrel{0}{\hat{s}} \\
\text { in }\end{array}$ & $\begin{array}{l}\stackrel{+}{6} \\
\stackrel{0}{0} \\
\stackrel{0}{r}\end{array}$ \\
\hline
\end{tabular}

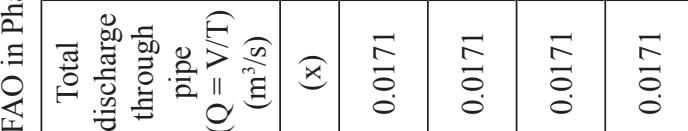

\begin{tabular}{|c|c|c|c|c|}
\hline 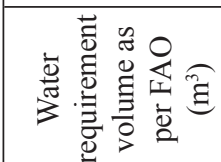 & $\nexists \nexists$ & â & & \\
\hline
\end{tabular}

(1)

त

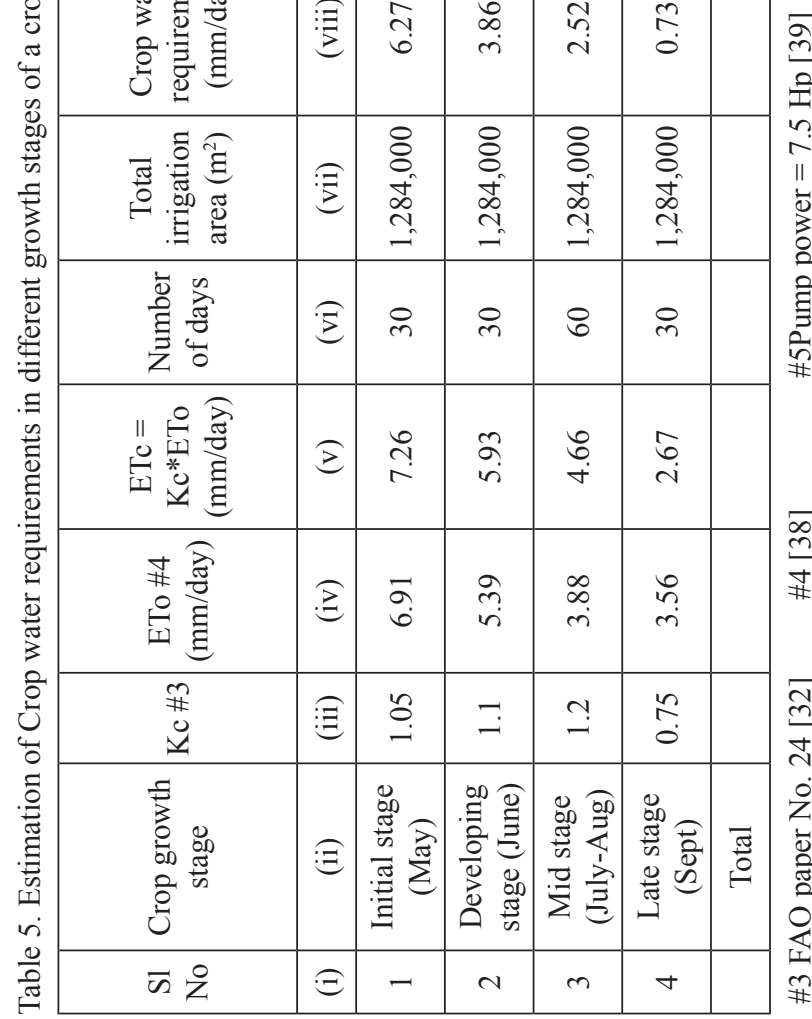

\begin{tabular}{|c|c|c|c|c|c|c|}
\hline 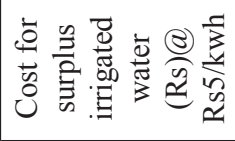 & 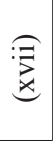 & $\begin{array}{l}\stackrel{2}{\vec{m}} \\
\text { m. } \\
\text { \&े }\end{array}$ & 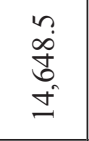 & $\begin{array}{l}\vec{y} \\
\tilde{n} \\
n \\
\dot{n}\end{array}$ & $\begin{array}{l}n \\
\infty \\
\infty \\
m \\
n \\
n\end{array}$ & $\begin{array}{l}\text { ¿े } \\
\text { +े }\end{array}$ \\
\hline 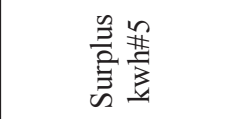 & 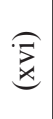 & $\begin{array}{l}\dot{\pi} \\
\dot{0} \\
\dot{+}\end{array}$ & $\begin{array}{l}\text { तें } \\
\text { ते }\end{array}$ & $\begin{array}{l}\stackrel{\circ}{\vec{\sigma}} \\
\stackrel{+}{+} \\
\stackrel{+}{*}\end{array}$ & $\begin{array}{l}\hat{0} \\
\dot{0} \\
i n\end{array}$ & $\begin{array}{l}\infty \\
\stackrel{0}{\infty} \\
\stackrel{0}{0} \\
0\end{array}$ \\
\hline 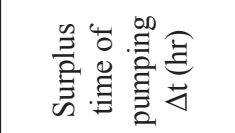 & $\underset{x}{\stackrel{x}{x}}$ & 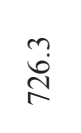 & $\begin{array}{l}\text { D. } \\
\text { ते }\end{array}$ & $\underset{\infty}{\stackrel{\infty}{\stackrel{\infty}{\infty}}}$ & 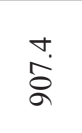 & ల్ \\
\hline 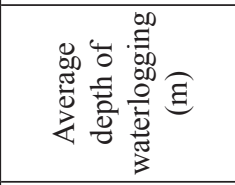 & 產 & $\stackrel{\infty}{\stackrel{\infty}{0}}$ & $\begin{array}{l}\infty \\
\infty \\
\stackrel{0}{1} \\
0\end{array}$ & $\frac{n}{\tilde{o}}$ & $\begin{array}{l}\text { ָี } \\
\text { }\end{array}$ & \\
\hline 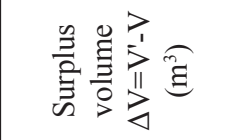 & : & $\begin{array}{l}\underset{\dot{a}}{\infty} \\
\dot{f} \\
\dot{f}\end{array}$ & 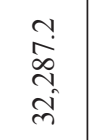 & 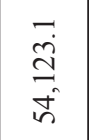 & $\begin{array}{l}\text { aे } \\
\text { कें } \\
\text { हैं } \\
\text { in }\end{array}$ & 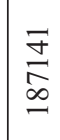 \\
\hline 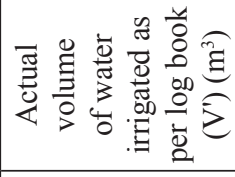 & : & 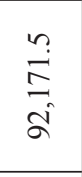 & 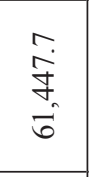 & 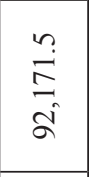 & $\begin{array}{l}\frac{1}{\dot{+}} \\
\frac{9}{6}\end{array}$ & 交 \\
\hline 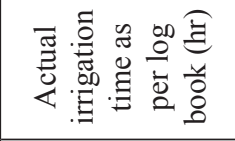 & ब्र & 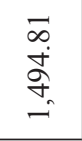 & 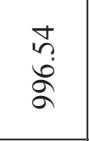 & \begin{tabular}{l}
$\vec{\infty}$ \\
+ \\
+ \\
\multirow{\sigma}{+}{} \\
-
\end{tabular} & 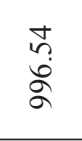 & \\
\hline 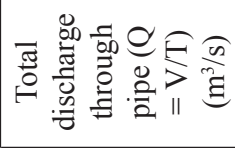 & $\underset{\star}{\star}$ & $\frac{}{\overrightarrow{0}}$ & 롱 & $\begin{array}{l}\vec{E} \\
\stackrel{0}{0}\end{array}$ & $\begin{array}{l}\overrightarrow{5} \\
\stackrel{0}{\circ}\end{array}$ & \\
\hline 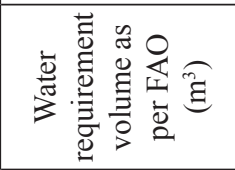 & 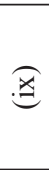 & 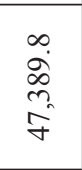 & 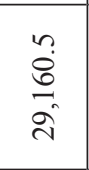 & 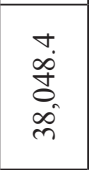 & $\begin{array}{l}\hat{\infty} \\
\text { ò } \\
\text { gn } \\
\text { n. }\end{array}$ & 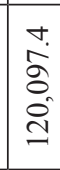 \\
\hline 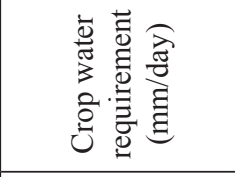 & 砉 & $\begin{array}{l}\infty \\
\stackrel{0}{0} \\
\text { b }\end{array}$ & $\begin{array}{l}\hat{n} \\
\infty \\
\dot{n}\end{array}$ & $\begin{array}{l}\stackrel{b}{n} \\
\vec{n}\end{array}$ & 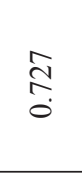 & \\
\hline 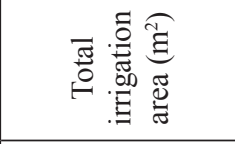 & 危 & $\begin{array}{l}8 \\
8 \\
\text { iิ } \\
\end{array}$ & 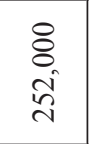 & $\begin{array}{l}8 \\
\vdots \\
i ̂ n \\
\end{array}$ & $\begin{array}{l}\text { \& } \\
\text { तิ } \\
\text { त̂ }\end{array}$ & \\
\hline 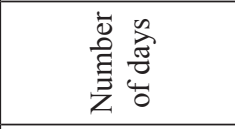 & है & $\stackrel{\text { m }}{\text { n }}$ & ஜे & 8 & $\stackrel{m}{2}$ & \\
\hline 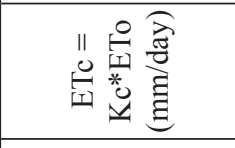 & E & ִָ & 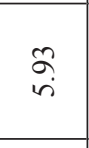 & $\begin{array}{l}\stackrel{8}{\circ} \\
+\end{array}$ & $\begin{array}{l}\hat{\sigma} \\
i\end{array}$ & \\
\hline 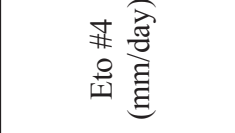 & $\Xi$ & बु. & ले & $\begin{array}{l}\infty \\
\infty \\
\infty \\
\dot{n}\end{array}$ & ஜூ & \\
\hline \begin{tabular}{l}
$\#$ \\
$\#$ \\
$\ddot{0}$ \\
\cline { 1 - 1 }
\end{tabular} & $\widehat{\Xi}$ & $\stackrel{\Omega}{.}$ & $\exists$ & $\stackrel{\sim}{\longrightarrow}$ & $\stackrel{n}{a}$ & \\
\hline 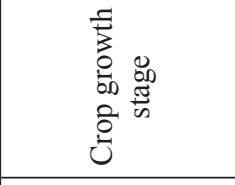 & 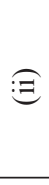 & 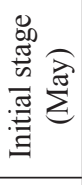 & 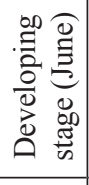 & 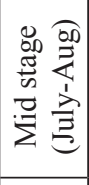 & 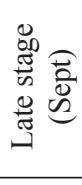 & 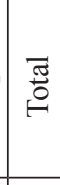 \\
\hline $\bar{n} z$ & $\Theta$ & - & N & $m$ & $\sigma$ & \\
\hline
\end{tabular}



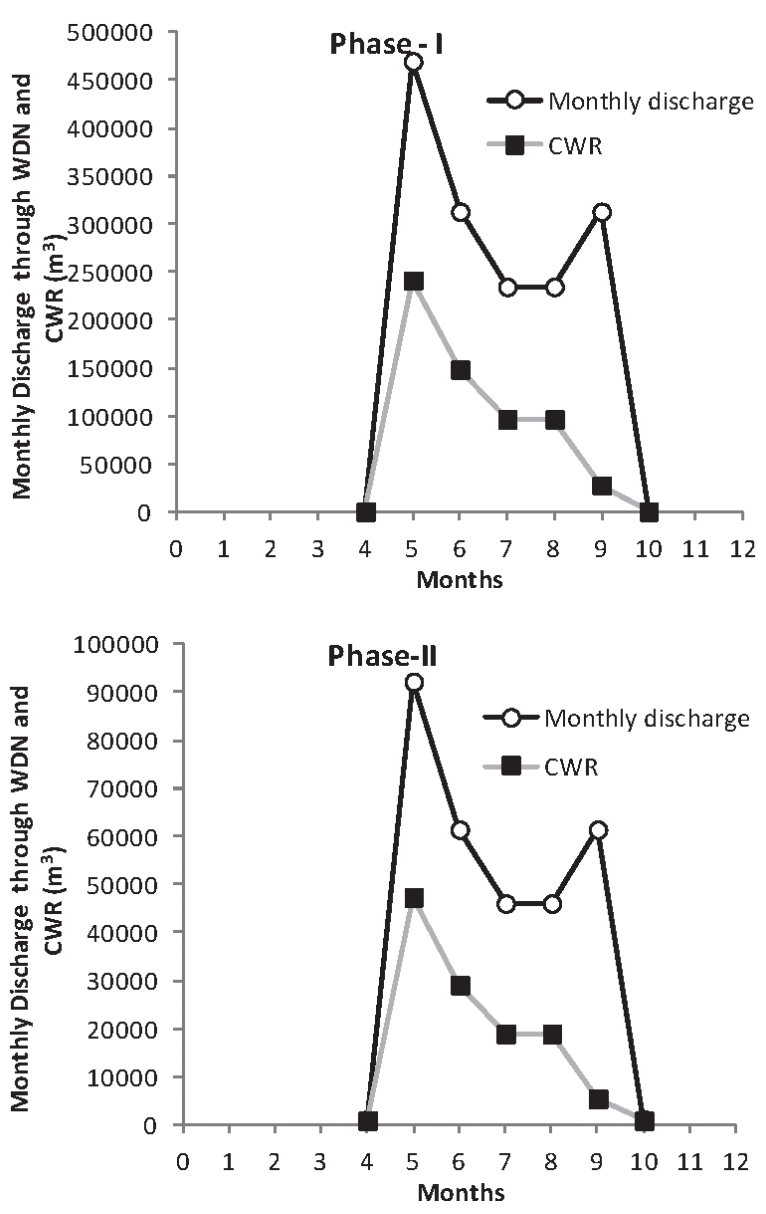

Fig. 4. Monthly irrigation through pipe discharge and corresponding crop water requirements in two study area (phases I and II).

Phase II is 1.2 lakh $\mathrm{m}^{3}$. In order to fulfil this requirement, irrigation was conducted through a pipe network. Fig. 4 shows monthly irrigation through pipe discharge and corresponding crop water requirements in two zones of the study area (phase I and phase II). It is observed that the crop water requirement is much less - about $50 \%$ of the irrigated water supplied through the pipeline. Especially in the month of September (i.e., in post monsoon) the amount of irrigated water is more. As a result, during the field survey water logging also was observed in the study area (Fig. 3d). In the following section, cost calculation based on the existing irrigation technique is done.

\section{Cost Calculation Based on Existing Irrigation Technique}

Total Discharge through the pipeline, actual volume of water irrigated as per the log book, average depth of waterlogging, time of pumping, and cost for surplus irrigated water are calculated and depicted in columns $\mathrm{x}$, xii, xiv, xv, and xvii of Table 5 for the existing irrigation technique in Phase I. In addition, similar calculations for Phase II are depicted in Table 6. We found that at a
Table 7. Details of Phase I Irrigation WDN with different nodes, junctions, and pipes.

\begin{tabular}{|c|c|c|c|c|c|}
\hline $\begin{array}{l}\text { Node } \\
\text { ID }\end{array}$ & $\begin{array}{l}\text { Elevation } \\
\text { (m) }\end{array}$ & $\begin{array}{c}\text { Demand } \\
\left(\mathrm{m}^{3} / \mathrm{s}\right)\end{array}$ & $\begin{array}{l}\text { Pipe/ } \\
\text { Link ID }\end{array}$ & $\begin{array}{l}\text { Diameter } \\
(\mathrm{mm})\end{array}$ & $\begin{array}{l}\text { Length } \\
\text { (m) }\end{array}$ \\
\hline J 12 & 53 & 0.0030 & P 17 & 80 & 11 \\
\hline \multirow{2}{*}{ J 13} & \multirow{2}{*}{53} & \multirow{2}{*}{0} & P 19 & 80 & 20 \\
\hline & & & P 17 & 80 & 11 \\
\hline \multirow{2}{*}{ J 14} & \multirow{2}{*}{53} & \multirow{2}{*}{0} & P 18 & 80 & 17 \\
\hline & & & P 19 & 80 & 20 \\
\hline \multirow{2}{*}{ J 15} & \multirow{2}{*}{52} & \multirow{2}{*}{0} & P 14 & 80 & 52 \\
\hline & & & P 18 & 80 & 17 \\
\hline J 16 & 53 & 0.0020 & P 08 & 80 & 30 \\
\hline \multirow{5}{*}{ J 17} & \multirow{5}{*}{53} & \multirow{5}{*}{0} & $\mathrm{P} 4$ & 80 & 5 \\
\hline & & & P 14 & 80 & 52 \\
\hline & & & P 8 & 80 & 30 \\
\hline & & & P 12 & 80 & 17 \\
\hline & & & P 10 & 80 & 24 \\
\hline \multirow{2}{*}{ J 18} & \multirow{2}{*}{51} & \multirow{2}{*}{0} & P 12 & 80 & 17 \\
\hline & & & P 13 & 80 & 83 \\
\hline \multirow{2}{*}{ J 19} & \multirow{2}{*}{52} & \multirow{2}{*}{0} & P 10 & 80 & 24 \\
\hline & & & P 11 & 80 & 46 \\
\hline J 20 & 52 & 0.0071 & P 11 & 80 & 46 \\
\hline J 21 & 51 & 0.0050 & P 13 & 80 & 83 \\
\hline R 1 & 40 & & P 1 & 100 & 20 \\
\hline \multirow{2}{*}{ FCV 1} & \multirow{2}{*}{53} & & P 3 & 80 & 5 \\
\hline & & & P 4 & 80 & 5 \\
\hline \multirow{2}{*}{ PMP 1} & \multirow{2}{*}{36} & & P 1 & 100 & 20 \\
\hline & & & P 2 & 80 & 5 \\
\hline \multirow{2}{*}{ ST 1} & \multirow{2}{*}{55} & & P 3 & 80 & 5 \\
\hline & & & $\mathrm{P} 2$ & 80 & 5 \\
\hline Total & & 0.0171 & & & \\
\hline
\end{tabular}

rate of INR 5 per unit $\mathrm{kWh}$, the cost of annual surplus irrigated water is 4.32 lakhs for an irrigation area of $1.284 \mathrm{~km}^{2}$ (Phase I), and the same is INR 0.84 lakh for $0.252 \mathrm{~km}^{2}$ (Phase II). This loss can be minimised using proper regulation of irrigated water using WDN, which is discussed in the following section.

\section{Steady and Transient Analysis of WDN of the Study Area}

Steady and transient flow analysis of the study area was performed in HAMMER software. Preliminary data, viz., elevation of each node, length of the links (pipeline segments), diameter of pipeline, valve information (their 
Table 8. Details of Phase II irrigation WDN with different nodes, junctions, and pipes.

\begin{tabular}{|c|c|c|c|c|c|}
\hline $\begin{array}{l}\text { Node } \\
\text { ID }\end{array}$ & $\begin{array}{l}\text { Elevation } \\
\text { (m) }\end{array}$ & $\begin{array}{c}\text { Demand } \\
\left(\mathrm{m}^{3} / \mathrm{s}\right)\end{array}$ & $\begin{array}{l}\text { Pipe/ } \\
\text { Link ID }\end{array}$ & $\begin{array}{c}\text { Diameter } \\
(\mathrm{mm})\end{array}$ & $\begin{array}{l}\text { Length } \\
(\mathrm{m})\end{array}$ \\
\hline \multirow{5}{*}{$\mathrm{J} 1$} & \multirow{5}{*}{53} & \multirow{5}{*}{0} & P 4 & 80 & 05 \\
\hline & & & P 5 & 80 & 70 \\
\hline & & & P 12 & 80 & 28 \\
\hline & & & P 16 & 80 & 25 \\
\hline & & & P 18 & 80 & 83 \\
\hline $\mathrm{J} 2$ & 52 & 0.0050 & P 5 & 80 & 70 \\
\hline J 3 & 51 & 0.0071 & P 15 & 80 & 45 \\
\hline $\mathrm{J} 4$ & 53 & 0.0030 & P 11 & 80 & 30 \\
\hline J 5 & 52 & 0.0020 & P 17 & 80 & 05 \\
\hline \multirow{2}{*}{ J 6} & \multirow{2}{*}{51} & \multirow{2}{*}{0} & P 19 & 80 & 70 \\
\hline & & & P 11 & 80 & 30 \\
\hline \multirow{2}{*}{ J 7} & \multirow{2}{*}{51} & \multirow{2}{*}{0} & P 12 & 80 & 28 \\
\hline & & & P 14 & 80 & 27 \\
\hline \multirow{2}{*}{ J 8} & \multirow{2}{*}{51} & \multirow{2}{*}{0} & P 14 & 80 & 27 \\
\hline & & & P 15 & 80 & 45 \\
\hline \multirow{2}{*}{ J 9} & \multirow{2}{*}{52} & \multirow{2}{*}{0} & P 16 & 80 & 25 \\
\hline & & & P 17 & 80 & 05 \\
\hline \multirow{2}{*}{ J 10} & \multirow{2}{*}{51} & \multirow{2}{*}{0} & P 18 & 80 & 83 \\
\hline & & & P 9 & 80 & 70 \\
\hline Res 1 & 40 & & P 1 & 100 & 20 \\
\hline \multirow{2}{*}{ FCV 1} & \multirow{2}{*}{53} & & P 3 & 80 & 05 \\
\hline & & & P 4 & 80 & 05 \\
\hline \multirow{2}{*}{ PMP 1} & \multirow{2}{*}{36} & & P 1 & 100 & 20 \\
\hline & & & P 2 & 80 & 05 \\
\hline \multirow{2}{*}{ ST 1} & \multirow{2}{*}{55} & & P 2 & 80 & 05 \\
\hline & & & P 3 & 80 & 05 \\
\hline Total & & 0.0171 & & & \\
\hline
\end{tabular}

locations and demand at different nodes, etc.) used in HAMMER are shown in Tables 7 and 8 for phases I and II, respectively. Demands at different nodes are calculated based on information obtained in the field survey and corresponding to column ix of Tables 3 and 4. Different paths are selected for transient analysis.

For Phase I, route PMP1-ST1-FCV1-J17-J19-J20 is named path 1, route PMP1-ST1-FCV1-J17-J18-J21 is named path 2, and route PMP1-ST1-FCV1-J17-J15-J14J13-J12 is named path 3. Pressure distribution in different nodes along all three paths are shown in Figs 5(a-c). For this analysis time $t$ is considered $240 \mathrm{sec}$, water level $\mathrm{h}$ is considered as 4 inches, and discharge $\mathrm{Q}$ is considered as $0.00171 \mathrm{~m}^{3} / \mathrm{s}$.
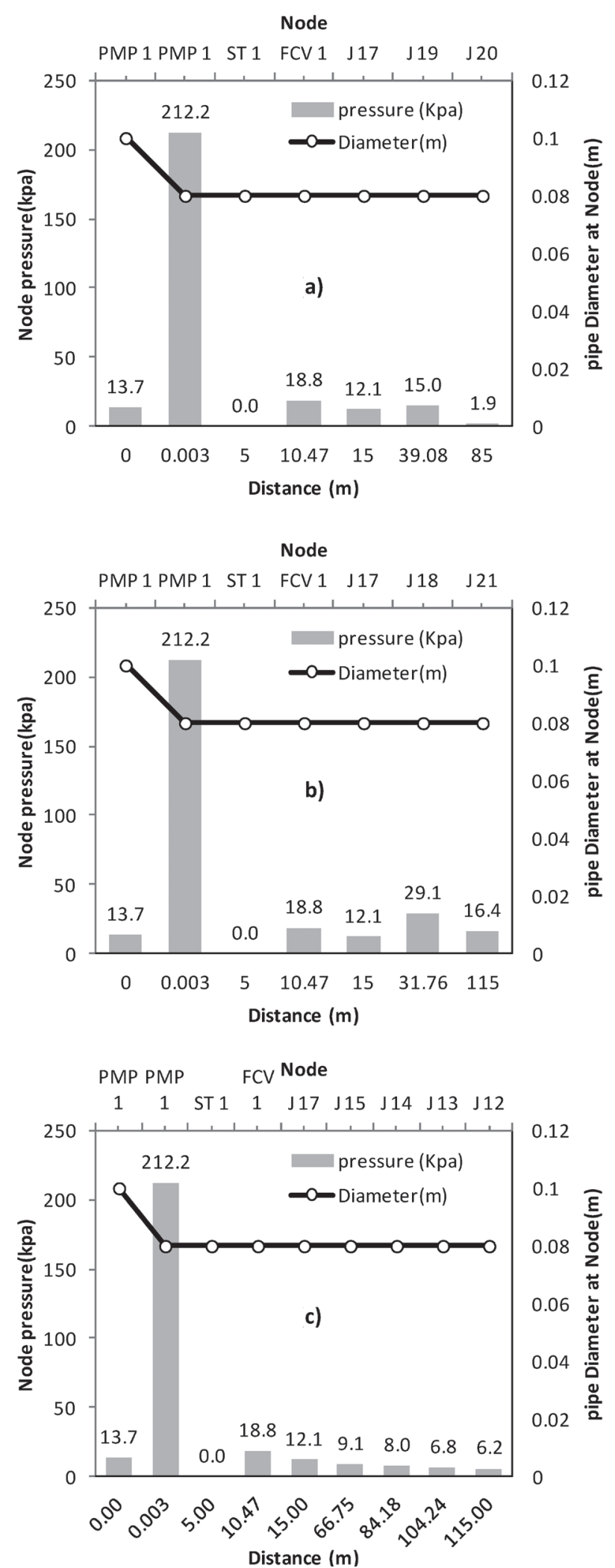

Fig. 5. Pressure distribution at different nodes in Phase I: a) along path $1, \mathrm{~b}$ ) along path 2 , and c) along 3 .

For Phase II, route PMP1-ST1-FCV1-J1-J7-J8-J3 is named path 12, route PMP1-ST1-FCV1-J17-J18-J21 is path 22, and route PMP1-ST1-FCV1-J1-J10-J6-J4 is path 32. Pressure distribution in different nodes along all three 

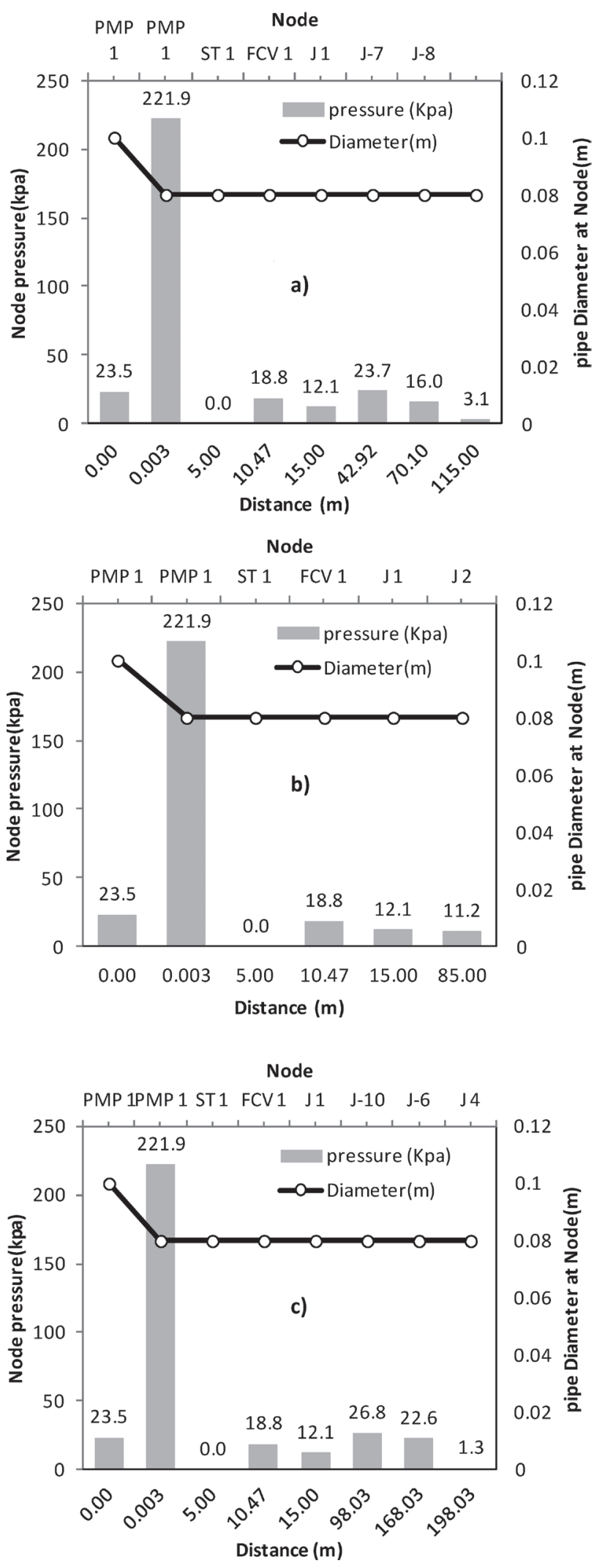

Fig. 6. Pressure distribution at different nodes in Phase II: a) along path $12, \mathrm{~b}$ ) along path 22, and c) along path 32 .

paths are shown in Figs 6(a-c). For this analysis time $t$ is considered $240 \mathrm{sec}$, water level $\mathrm{h}$ is considered 4 inches, and discharge Q is considered $0.00171 \mathrm{~m}^{3} / \mathrm{s}$.
It is observed that as distance between the nodes increases, pressure drop occurs because of different major and minor losses in the pipeline where diameter of the pipeline is still constant. This is observed in both WDNs of phases I and II. However, as J17 in Phase I WDN is a junction between the node of $\mathrm{J} 19, \mathrm{~J} 18$, and $\mathrm{J} 14$, the pressure at J17 is suddenly reduced. Similar pressure distribution also is observed in Phase II WDN. Here J1 is the junction of J7, J2, and J10. Through the above calculation a proper pumping schedule can be made based on actual crop water requirements in order to reduce surplus irrigated water, i.e., by reducing excess pumping cost of total INR 5.16 lakh, which is to be paid by the farmer.

\section{Conclusions}

In this paper the crop irrigation requirement for rice production is estimated for the study area. The study area (phases I and II) belongs to a humid subtropical region with sandy clay loam soil. Here farmers are following partial border strips like irrigation technique with supply pipe and riser. Initially the Man Kendall trend test is performed on six year of (2004-2010) monthly rainfall data. We found that the data has no trend at a 5\% significance level. Thereafter, average monthly rainfall is used to calculate effective rainfall using the USDA Soil Conservation Service method. Other parameters like ETo and $\mathrm{Kc}$ are calculated based on FAO guidelines. Finally, crop water requirement in the study area amounted to 7.22 lakh $\mathrm{m}^{3}$, of which Phase I is 6.12 lakh $^{3}$ and Phase II is 1.2 lakh $\mathrm{m}^{3}$. In the study area, farmers generally irrigate their land through a pipe network. Actual irrigation values are calculated based on four years of water distribution data collected during the field survey. Fig. 4 shows monthly irrigation through pipe discharge and the corresponding crop water requirement in two zones of the study area (phases I and II). We observed that the crop water requirement is much less - about $50 \%$ of the irrigated water supplied through the pipeline. As a result, during the field survey waterlogging also was observed in the study area (Fig. 3d). Finally, average depth of waterlogging, time of pumping, and cost for surplus irrigated water are calculated for the study area and depicted in Tables 5 and 6 . It is found that at a rate of INR 5 per unit kWh, the cost of annual surplus irrigated water is 4.32 lakhs for an irrigation area of $1.284 \mathrm{~km}^{2}$ (Phase I), and the same is INR 0.84 lakh for $0.252 \mathrm{~km}^{2}$ (Phase II). This loss can be minimised using proper regulation of irrigated water using the water distribution network.

It seems a full-phased piping network may work well in this area, and implementing a water meter, adjusting crop planting patterns, and adopting proper irrigation technique may reduce water use (i.e., the cost of irrigation) [16]. Moreover, the problem can be resolved by partly utilizing Muhane River water (Fig. 2) and additional - if required - groundwater for irrigation in order to maintain the ground water level. 


\section{Acknowledgements}

We would like to thank the Minor Research Project, TEQIP II, ISM Dhanbad for funding this project, and the Minor Irrigation Division, Nalanda, Bihar Sharif(formerly Nalkup Parimandal) for giving permission to access their irrigation data. We also thank the Department of Mechanical Engineering, Indian Institute of Technology (ISM) Dhanbad for providing a facility for our project work, and the departments of Civil Engineering, Applied Chemistry, and Environment Science and Engineering at the Indian Institute of Technology (ISM) Dhanbad for the support necessary for carrying out some of our laboratory tests.

\section{References}

1. RECA J., GARCÍA-MANZANO A., MARTÍNEZ J. Optimal pumping scheduling model considering reservoir evaporation. Agricultural Water Management. 148, 250, 2014.

2. RECA J., GARCÍA-MANZANO A., MARTÍNEZ J. Optimal pumping scheduling for complex irrigation water distribution systems. Journal of Water Resources Planning and Management. 140 (5), 630, 2014.

3. SINGH A.K., VERMA C.L., SINGH Y.P., BHARDWAJ A.K., ARORA S., SINGH D. Irrigation water and pumping energy use trends in rice (Oryza sativa L.) under varying irrigation regimes in partially reclaimed sodic soils. Journal of Soil and Water Conservation. 15 (1), 52. 2016.

4. MORADI-JALAL M., MARIÑO M.A., AFSHAR A. Optimal design and operation of irrigation pumping stations. J. Irrig. Drain. Eng., 129 (3), 149, 2003.

5. PLANELLS P., CARRIÓN P., ORTEGA J.F., MORENO M.A., TARJUELO J.M. Pumping selection and regulation for water-distribution networks. Journal of Irrigation and Drainage Engineering, 131 (3) 273, 2005.

6. PULIDO-CALVO I., GUTIÉRREZ-ESTRADA J.C. Selection and operation of pumping stations of water distribution systems. Environmental Research Journal, Nova Science Publishers. 5 (3), 1, 2011.

7. DUKE H.R., HEERMANN D.F., BLUE M.C. Computer control of irrigation for electrical load management. Trans. ASAE, 27, 597-602 \& 608, 1984.

8. HEERMANN D.F., BUCHLEITER G.W., DUKE H.R. Integrated water-energy management system for centre pivot irrigation: implementation. Trans. ASAE, 27, 1424, 1984.

9. PEREA R.G., POYATO E.C., MONTESINOS P., DÍAZ J.R. Optimization of irrigation scheduling using soil water balance and genetic algorithms. Water Resources Management, 30 (8), 2815, 2016.

10. SADATI S.K., SPEELMAN S., SABOUHI M., GITIZADEH M., GHAHRAMAN B. Optimal irrigation water allocation using a genetic algorithm under various weather conditions. Water. 6 (10), 3068, 2014.

11. ALLRED B.J., REDMAN D.J. Location of Agricultural Drainage Pipes and Assessment of Agricultural Drainage Pipe Conditions Using Ground Penetrating Radar, Journal of Environmental and Engineering Geophysics (JEEG), September 2010, 15 (3), 119, 2010.

12. RAHMAN M.M., KAMAL A.H.M., MAMUN A.A., MIAH M.S.U. Study on the irrigation water distribution system developed by barind multipurpose development authority, Journal of the Bangladesh Association of Young Researchers (JBAYR). 1 (2), 63, 2011.

13. PULIDO-CALVO I., GUTIÉRREZ-ESTRADAJ.C. Selection and operation of pumping stations of water distribution systems, Environmental Research Journal, 5 (3), 1, 2011.

14. CAO X., WU P., WANG Y., ZHAO X. Challenge of water sources in urbanizing China: an analysis of agricultural water footprint. Polish Journal of Environmental Studies. 24 (1), 9, 2015.

15. XIAO M., MIAO Z., LI Y. Changes of Root-Zone Soil Environment in Flooded Paddy Field under Controlled Drainage Conditions. Polish Journal of Environmental Studies. 26 (2), 2017.

16. SHEN Y., LI S., CHEN Y., QI Y., ZHANG S. Estimation of regional irrigation water requirement and water supply risk in the arid region of Northwestern China 19892010. Agricultural Water Management. 128, 55, 2013.

17. YE Q., YANG X., DAI S., CHEN G., LI Y., ZHANG C. Effects of climate change on suitable rice cropping areas, cropping systems and crop water requirements in southern China. Agricultural Water Management. 159, 35, 2015.

18. CHELLATTAN VEETTIL P., SPEELMAN S., FRIJA A., BUYSSE J., MONDELAERS K.,VAN HUYLENBROECK G. Price Sensitivity of Farmer Preferences for Irrigation Water-Pricing Method: Evidence from a Choice Model Analysis in Krishna River Basin, India. Journal of Water Resources Planning and Management. 137 (2), 205, 2010.

19. FISHMAN R., LALL U., MODI V., PAREKH N. Can Electricity Pricing Save India's Groundwater? Field Evidence from a Novel Policy Mechanism in Gujarat. Journal of the Association of Environmental and Resource Economists. 3 (4), 819, 2016.

20. PANDEY R. Groundwater Irrigation in Punjab: Some Issues and a Way Forward. In Economic Transformation of a Developing Economy. 97, 2016.

21. BASSI N. Groundwater Depletion in India: Potential of Alternative Approaches and Policy Instruments. In Indian Water Policy at the Crossroads: Resources, Technology and Reforms Springer International Publishing. 35, 2016.

22. MUKHERJEE S., BISWAS D. An Enquiry into Equity Impact of Groundwater Markets in the Context of Subsidised Energy Pricing: A Case Study. IIM Kozhikode Society \& Management Review. 5 (1), 63, 2016.

23. KUMAR M.D. Distressed elephants: policy initiatives for sustainable groundwater management in India. IIM Kozhikode Society \& Management Review. 5 (1), 51, 2016.

24. MUKHERJI A., DAS B., MAJUMDAR N., NAYAK N. C., SETHI R. R., SHARMA, B. R. Metering of agricultural power supply in West Bengal, India: Who gains and who loses?. Energy Policy. 37 (12), 5530, 2009.

25. MSANGI S., CLINE S.A. Improving Groundwater Management for Indian Agriculture: Assessing Tradeoffs Across Policy Instruments. Water Economics and Policy. 2 (3), 1650027, 2016.

26. SINGH A.K., ARORA S., SINGH Y.P., VERMA C.L., SRIVASTAVA A., SHARMA N. Enhancing irrigation water productivity in paddy grown under sodic environment. Journal of Soil and Water Conservation. 16, (1), 67, 2017.

27. SINGH A. Hydrological problems of water resources in irrigated agriculture: A management perspective. Journal of Hydrology. 541, 1430, 2016.

28. ZEKRI S. Using economic incentives and regulations to reduce seawater intrusion in the Batinah coastal area of Oman. Agricultural Water Management 95 (3), 2008. 
<www.cwc.nic.in/Water Data Pocket 2006/TB.2find. pdf $>$. Accesses 12 July 2016.

29. DE MOOR A., CALAMAI P. Subsidizing unsustainable development-undermining the earth with public funds. The Earth Council. 1997.

30. SHAH T. Wells and Welfare in Ganga Basin: Public Policy and Private Initiative in Eastern Uttar Pradesh, India, Research Report 54, International Water Management Institute, Colombo, Sri Lanka. 2001.

31. ALAM F. Ground Water Information Booklet Nalanda, Central Ground water Board Ministry of Water Resources Mid-Eastern Region Patna, 2013.

32. DORENBOS J., PRUITT W.O. Guideline for predicting crop water requirement. FAO irrigation and drainage paper 24. The Food and Agriculture Organization of the United Nations (FAO), Rome, 1977.

33. KUMAR D., ADAMOWSKI J., SURESH R., OZGAZIELINSKI B. Estimating Evapotranspiration Using an Extreme Learning Machine Model: Case Study in North Bihar, India. Journal of Irrigation and Drainage Engineering. 142 (9), 04016032, 2016.

34. BANDYOPADHYAY A., BHADRA A., RAGHUWANSHI N. S., SINGH R. Temporal trends in estimates of reference evapotranspiration over India. Journal of Hydrologic Engineering. 14 (5), 508, 2009.

35. YUE S., PILON P., CAVADIAS G. Power of the MannKendall and Spearman's Rho tests for detecting monotonic trends in hydrologic series. Journal of Hydrology 259 (1-4), 254, 2002.

36. KRISHAN R., SINGH P., UPADHYAYA A., ROY L.B Irrigation scheduling in Patna area "A case study for Maize" International Journal of Research Review in Engineering Science and Technology. 4 (1), 334, 2015.

37. NBSSLUP (National Bureau of Soil Survey and land Use Planning- Indian Council of Agricultural research - ICAR, Nagpur) Agro Ecological Regions India, Govt. of India, 1990.

38. NAG A., ADAMALA S., RAGHUWANSHI N.S., SINGH R., BANDYOPADHYAY A. "Estimation and Ranking of Reference Evapotranspiration for Different Spatial Scales in India”. Journal of Indian Water Resources Society, 34 (3), 35, 2014.

39. MINOR IRRIGATION DIVISION OFFICE. Project report setting up pilot project of PV system state owned Irrigation pumps in Bihar: Minor irrigation division Office Nalanda, 2013. 